\title{
SATELLITE-DERIVED PRIMARY PRODUCTIVITY AND ITS SPATIAL AND TEMPORAL VARIABILITY IN THE KHURE- MUSSA (NORTHWEST PERSIAN GULF)
}

\author{
Mosavi DeHMORDI, L. ${ }^{1 *}$ - SAVARI, A. ${ }^{1}$ - DostShenAS, B. ${ }^{1}$ - MOHAMAD ASGARI, H. ${ }^{2}$ - ABASI, A. ${ }^{3}$ \\ ${ }^{I}$ Department of Marine Biology, Faculty of Marine Science and Technology, Khorramshahr \\ University of Marine Science and Technology, Khorramshahr, Iran \\ ${ }^{2}$ Department of Environment, Faculty of Sea Natural Resources, Khorramshahr University of \\ Marine Science and Technology, Khorramshahr, Iran \\ ${ }^{3}$ Army Geographic Agency, Tehran, Iran \\ *Corresponding author \\ e-mail: Lalehmosavi84@yahoo.com \\ (tel.:+98-09163095923) \\ (Received $13^{\text {th }}$ Jan 2016; accepted $30^{\text {th }}$ May 2016)
}

\begin{abstract}
The vertically generalized production model (VGPM), which was designed for open ocean waters (Behrenfeld and Falkowski, 1997), was evaluated using in situ measurements of primary productivity (PP) in the characteristically turbid coastal waters of Khure-Mussa, in northwest Persian Gulf, to develop a regionally modified version of the model. The euphotic depth $\left(Z_{\text {eu }}\right)$-integrated PP (IPP) calculated from the VGPM using in situ chlorophyll a (Chla), sea surface temperature (SST) and Zeu was significantly underestimated but $59 \%$ of the observed variability was explained. The weak correlation could have partially resulted from overestimations by the sub-models embedded in the original VGPM model for estimation of $\mathrm{Z}_{\mathrm{eu}}$ (Morel and Berthon, 1989) and the optimal Chla-normalized PP ( $\mathrm{P}_{\text {opt }}^{\mathrm{B}}$ ). Chla was the most important parameter influencing the modeled IPP variation in Khure-Mussa. The modeled and in situ $\mathrm{P}_{\text {opt }}^{\mathrm{B}}$ were weakly correlated. This NPP model for the Khure-Mussa incorporates an improved prediction of the $\mathrm{P}^{\mathrm{B}}{ }_{\text {opt }}$, as a function of sea surface temperature (SST). The estimation of Chla was improved by optimizing the Chla algorithm with in situ Rrs data. The daily average of primary productivity in the whole Khure-Mussa was $0.63 \mathrm{gcm}^{-2} \mathrm{~d}^{-1}$. Thus, even though the VGPM is a global open ocean model, when coupled with turbid water algorithms for Zeu and Chla and modeled $\mathrm{P}^{\mathrm{B}}{ }_{\text {opt }}$, it provided realistic estimates of IPP in the turbid water ecosystem of Khure-Mussa.
\end{abstract}

Keywords: ocean, VGPM model, chlorophyll, carbon dioxide, ecology, temporal pattern

\section{Introduction}

Ocean primary productivity controls the exchange of carbon dioxide at the air-sea interface and plays an important role in the global carbon dioxide cycle and climate change. Furthermore, primary production is the base of the food web in marine ecosystems, and it influences the nature of marine food webs and abundance of marine organisms (Son et al., 2014). Continental shelf areas may account for $21 \%$ of global primary productivity (Walsh et al., 2004). Khure- Mussa consists of a basin that is surrounded by corona of many tidal creeks of varying length and width, and is linked to the Persian Gulf via a $50 \mathrm{~km}$ long estuary-like channel (Hopner and Maraschi, 1999). This estuary, one of the biggest estuaries in the Persian Gulf, is the most important fishery resource for people of Mashahr, Sarbandar and Hendijan cities (Khalfehnilsaz, 2000). Ship-based investigations of primary productivity in the Khure-Mussa have previously concentrated on areas around Mahshahr (Khalfehnilsaz, 2000;؛ Habibikhaledi, 2001); however, cruise scan only covered a very limited temporal and 
spatial range. Recently, some models have been developed to estimate primary productivity using satellite-derived data (Platt and Sathyendranath, 1999; Platt et al., 1991; Behrenfeld and Falkowski, 1997; Gong and Liu, 2003; Kameda, 2003; Kameda and Ishizaka, 2005; Tripathy et al., 2012; Nardello et al., 2013). Satellite-based instruments can measure key factors controlling primary productivity, such as chlorophyll-a concentration, sea surface temperature (SST), and photosynthetically active radiation (PAR), with high spatial and temporal resolution. However, primary production is a very complicated process and may be influenced by factors that affect the intensity of photosynthesis and chlorophyll-a concentration, such as SST, light, nutrients, optical properties, and phytoplankton respiration(Siegel et al., 2001; Behrenfeld et al., 2002; Campbell et al., 2002). In this study, we attempted to estimate primary productivity in the Khure-Mussa and to derive the spatial and temporal variability of primary productivity using satellite-derived chlorophyll a concentration, PAR, and SST data and primary productivity estimation with Vertically Generalized Production Model (VGPM).

\section{Materials and methods}

\section{Field observation}

The sampling site was located in western north of Persian Gulf (Figure 1). Data collection started on the $14^{\text {th }}$ Feb 2014 and ended on the $13^{\text {th }}$ Nov 2014, with 8 sampling trips carried out. The daily total photosynthetic active radiation $\left(\mathrm{E}_{0}\right)$ was recorded on deck with a surface hemispherical scalar irradiance sensor (QSR-240, Biospherical Inc.). The mean downwelling attenuation coefficient $\left(K_{d}\right)$ was obtained from a linear regression of the log-transformed underwater irradiance profiles which were measured with a Biospherical log quantum scalar irradiance sensor (4p; QSP-200L). Primary productivity was measured using the ${ }^{14} \mathrm{C}$ assimilation method (Parsons et al., 1984). Optimal specific primary productivity $\left(\mathrm{P}^{\mathrm{B}}{ }_{\text {opt }}\right)$ was taken as maximum chlorophyllnormalized primary productivity within the euphotic zone. The euphotic zone-integrated primary production (IP) was computed by means of the trapezoidal rule.

In addition, the 8-month averaged merged chlorophyll a concentration was validated by the in situ chlorophyll a concentration measured in the Khure-Mussa by 8 research during Feb 2014 to Nov 2014. The surface water samples were collected at a depth of $0.5 \mathrm{~m}$ below the water-air surface. After sampling, water samples were conserved in bottles at a low temperature and then sent for laboratory analysis in the afternoon. Samples for chlorophyll a were filtered on $\mathrm{GF} / \mathrm{F}$ fiberglass filters ( $25 \mathrm{~mm}$ diameter). The Chla was extracted using acetone (100\%) and was measured using reverse-phase high-performance liquid chromatography (HPLC). The HPLC method employed was that proposed by Wright et al. (1991) slightly modified as per Hooker et al. (2000). 


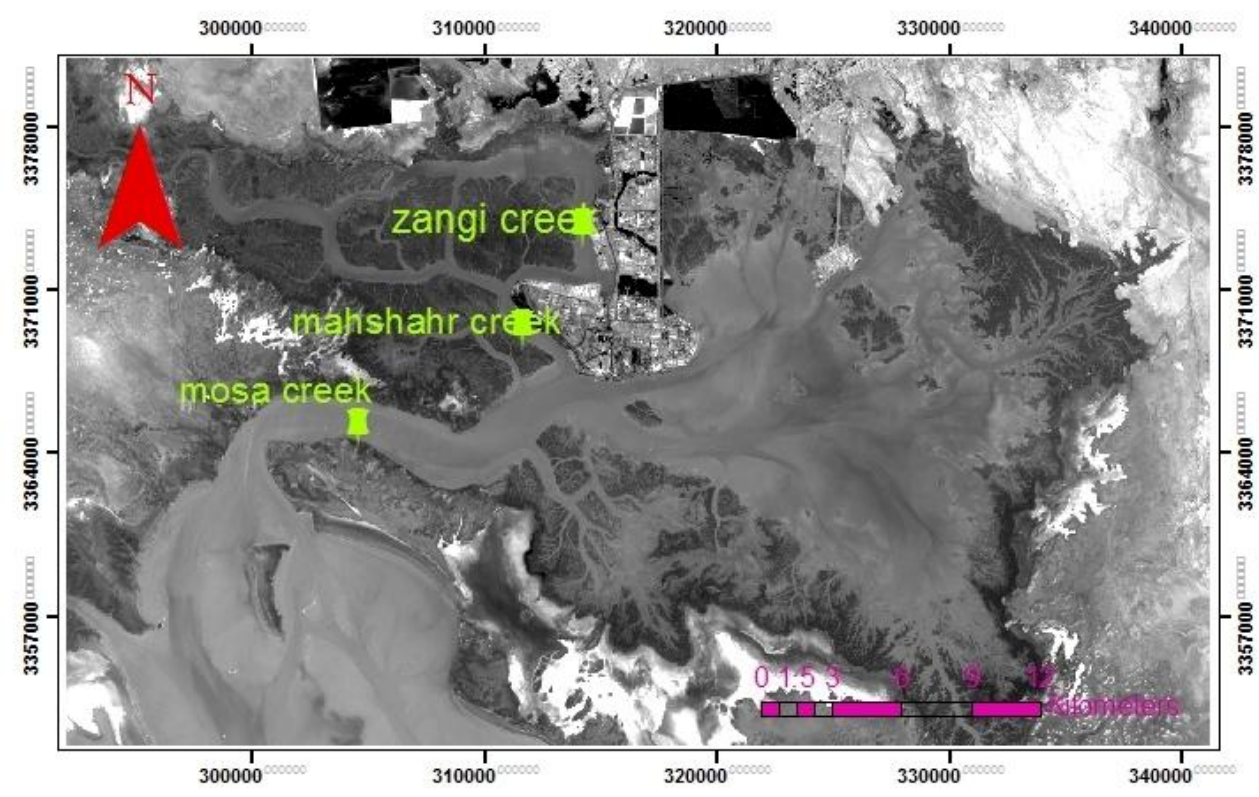

Figure 1. Location of the stations

\section{Satellite data}

Satellite-derived chlorophyll a concentration, $\mathrm{SST}$, and $\operatorname{PAR}\left(\mathrm{E}_{0}\right)$ data were applied to the VGPM. All the datasets had the same temporal resolution and $30 \times 30-\mathrm{m}$ spatial resolution and were provided by the National Aeronautics and Space Administration Goddard Space Flight Center Ocean Biology Processing Group (NASA GSFC OBPG). Atmospheric correction was conducted using method of dark object subtraction technique (DOS)(Kim et al., 2014). It is an image-based model that has been proposed to simplify atmospheric correction. The image were processed in Matlab software.

\section{Model of primary production}

VGPM model has been validated by thousands of real measuring data in the large scale and different water areas for a long time, therefore it has been used widely with accurate estimation results. Daily primary productivity is shown by the following equation(Behrenfeld and Falkowski, 1997):

$$
\mathrm{Pp}=0.66125 \times \mathrm{P}^{\mathrm{B}}{ }_{\mathrm{opt}} \times\left(\mathrm{E}_{0} / \mathrm{E}_{0}+4.1\right) \times \mathrm{Z}_{\mathrm{eu}} \times \mathrm{C}_{\mathrm{sat}} \times \mathrm{DL}
$$

where $P P_{e u}$ is integrated primary productivity in the euphotic zone $\left(\mathrm{mgCm}^{-2} \mathrm{~d}^{-1}\right), \mathrm{P}^{\mathrm{B}}$ opt is the maximum rate of daily photosynthesis within a water column $(\mathrm{mgC} / \mathrm{mgChla} / \mathrm{h}), E_{0}$ is daily PAR at the sea surface $\left(\right.$ Ein $\left.\mathrm{m}^{-2} \mathrm{~d}^{-1}\right), C_{\text {sat }}$ is the satellite-derived sea surface chlorophyll a concentration $\left(\mathrm{mgm}^{-3}\right), D L$ is the photoperiod $(\mathrm{h})$, and $Z_{e u}$ is the depth of the euphotic zone $(\mathrm{m})$ defined as the depth that $E_{0}$ decreases by $1 \%$, estimated by the sea surface chlorophyll a concentration using the following equations (Morel and Berthon, 1989):

$$
\mathrm{Z}_{\mathrm{eu}}=\left(568.2\left(\mathrm{C}_{\mathrm{tot}}\right)^{-0.746} \text { when } \mathrm{Z}_{\mathrm{eu}}<102 \leqq 200.0\left(\mathrm{C}_{\mathrm{tot}}\right)^{-0.293} \text { when } \mathrm{Z}_{\mathrm{eu}}>102\right)
$$




$$
\mathrm{C}_{\mathrm{tot}}=\left(38.0\left(\mathrm{C}_{\mathrm{sat}}\right) 0.425 \text { when } \mathrm{C}_{\mathrm{sat}}<1.0 \leqq 40.2\left(\mathrm{C}_{\mathrm{sat}}\right) 0.547 \text { when } \mathrm{C}_{\mathrm{sat}}>1.0\right)
$$

Considering the relationship between primary production and SST, Behrenfeld and Falkowski (1997) took the parameterization of $\mathrm{P}^{\mathrm{B}}{ }_{\text {opt }}$ as a seventh-order polynomial function of SST.

$\mathrm{P}_{\text {opt }}^{\mathrm{B}}=1.2956+2.749 \times 10^{-1} \mathrm{~T}+6.17 \times 10^{-2} \mathrm{~T}^{2}-2.05 \times 10^{-2} \mathrm{~T}^{3}+2.462 \times 10^{-3} \mathrm{~T}^{4}-1.348 \times 10^{-4} \mathrm{~T}^{5}$ $+3.4132 \times 10^{-3}$

\section{Results}

Temporal variations of measured and satellite $\mathrm{E}_{0}, \mathrm{SST}$, DL, Chla, $\mathrm{P}^{\mathrm{B}}{ }_{\text {opt }}, \mathrm{Z}_{\mathrm{eu}}, \mathrm{K}_{\mathrm{d}}(490)$, DL and IPP clearly emerged in this study (Fig. 2). The lowest $\mathrm{E}_{0}\left(31.12\right.$ Einstein $\mathrm{m}^{-2} \mathrm{~d}^{-1}$ ) were observed in Zangi in Feb and the highest $\mathrm{E}_{0}\left(47.49\right.$ Einstein $\mathrm{m}^{-2} \mathrm{~d}^{-1}$ ) were observed in July in Mosa creek. SST exhibited the most distinct temporal variation with the lowest $\left(15.1^{\circ} \mathrm{C}\right)$ in Zangi and the highest $\left(31^{\circ} \mathrm{C}\right)$ values in Mosa in February and July, respectively. The lowest Chla $\left(0.5 \mathrm{mgm}^{-3}\right)$ were observed in Zangi in Nov and the highest Chla $\left(1.8 \mathrm{mgm}^{-3}\right)$ were observed in April in Mosa creek. The lowest $Z_{\text {eu }}(5.35 \mathrm{~m})$ were observed in Zangi in May and the highest $\mathrm{Z}_{\text {eu }}(7.5 \mathrm{~m})$ were observed in Feb in Mahshahr creek. The lowest $\mathrm{K}_{\mathrm{d}}(490)(0.48 \mathrm{~m})$ were observed in Feb in Mahshahr creek and the highest $\mathrm{K}_{\mathrm{d}}(490)(0.67 \mathrm{~m})$ were observed in May in Zangi creek. The lowest Day length (10.3h) were observed in Nov and the highest Day lenght (14h) were observed in July. The lowest $\mathrm{P}^{\mathrm{B}}{ }_{\text {opt }}(4 \mathrm{mgc} / \mathrm{mgChla} / \mathrm{h})$ were observed in July in 3per creek and the highest $\mathrm{P}_{\text {opt }}^{\mathrm{B}}(6.59 \mathrm{mgc} / \mathrm{mgChla} / \mathrm{h})$ were observed in April in Mahshar creek. The lowest $\operatorname{IPP}\left(0.21 \mathrm{gc} / \mathrm{m}^{2} / \mathrm{d}\right)$ were observed in Nov in Zangi creek and the highest IPP $\left(2.11 \mathrm{gc} / \mathrm{m}^{2} / \mathrm{d}\right)$ were observed in April in Khure-Mussa.

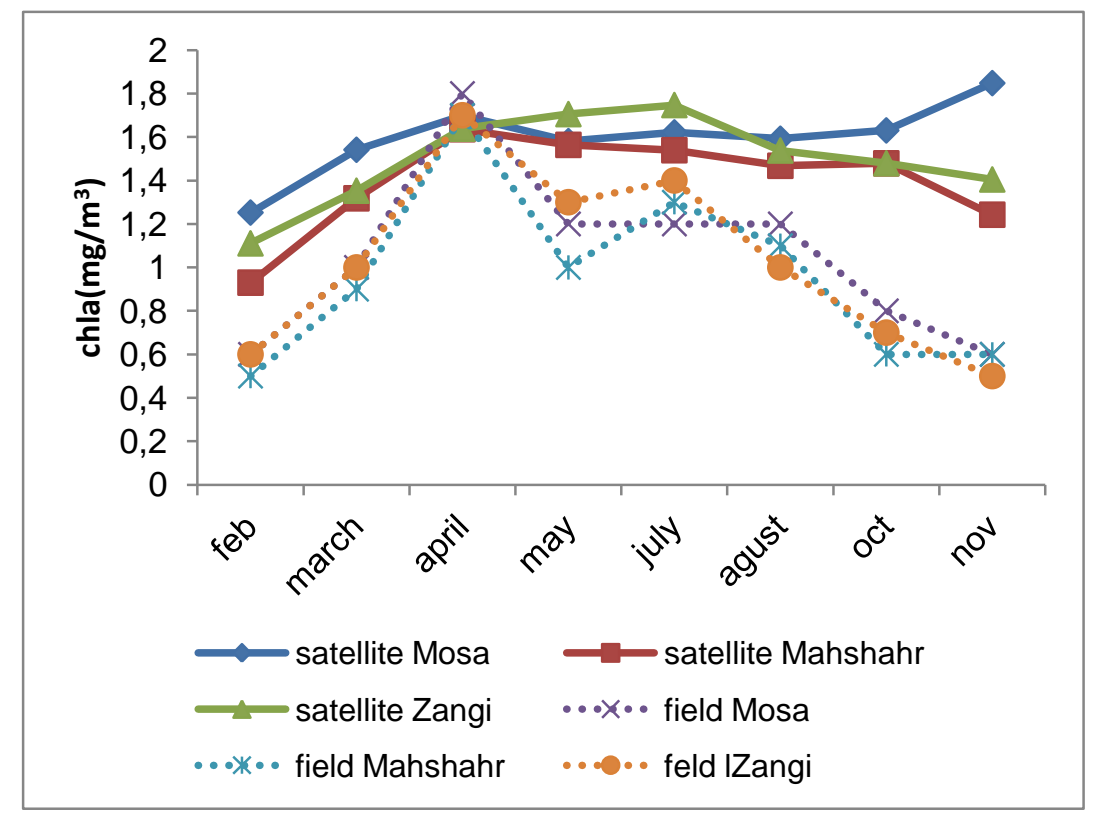



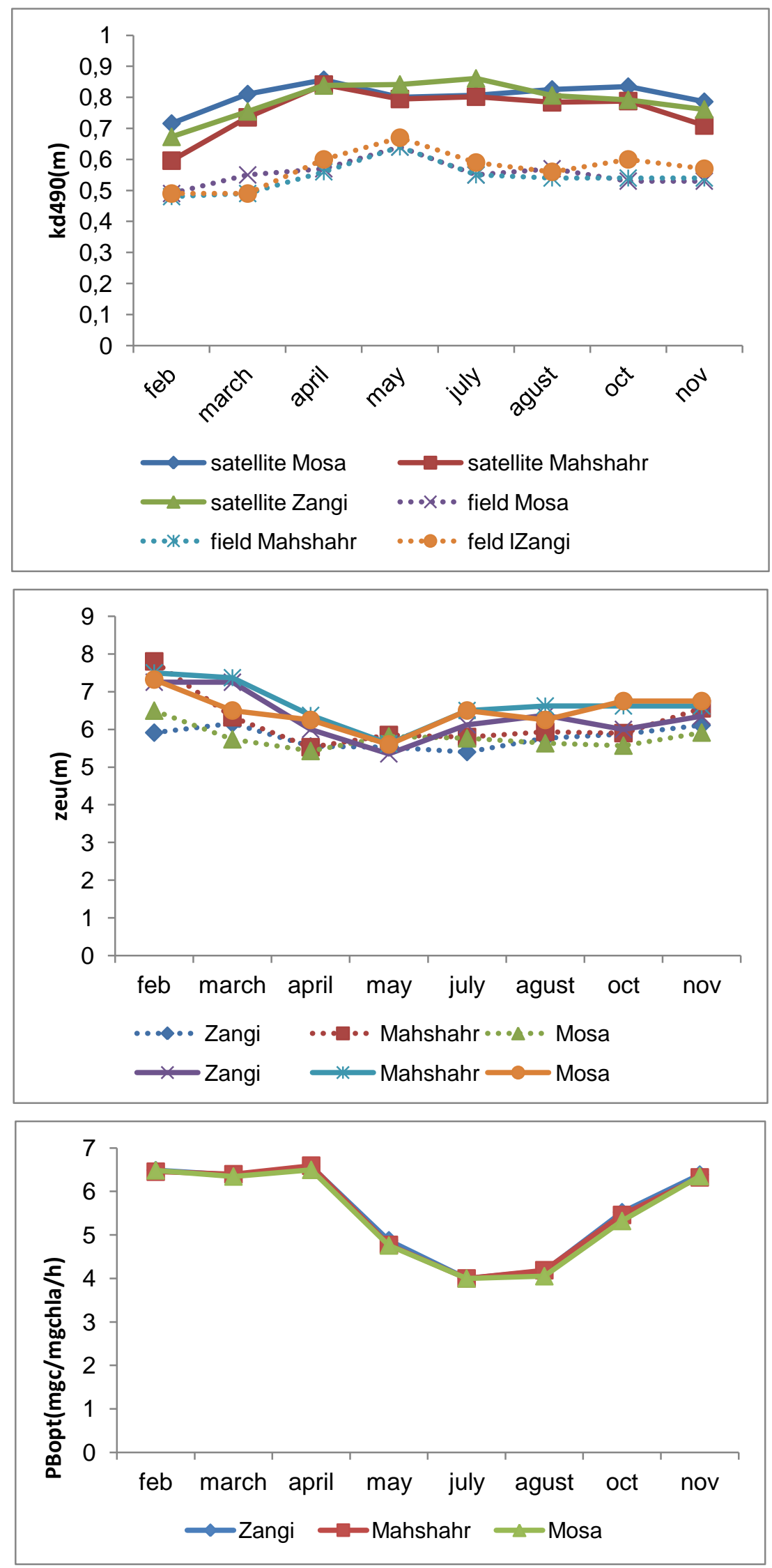

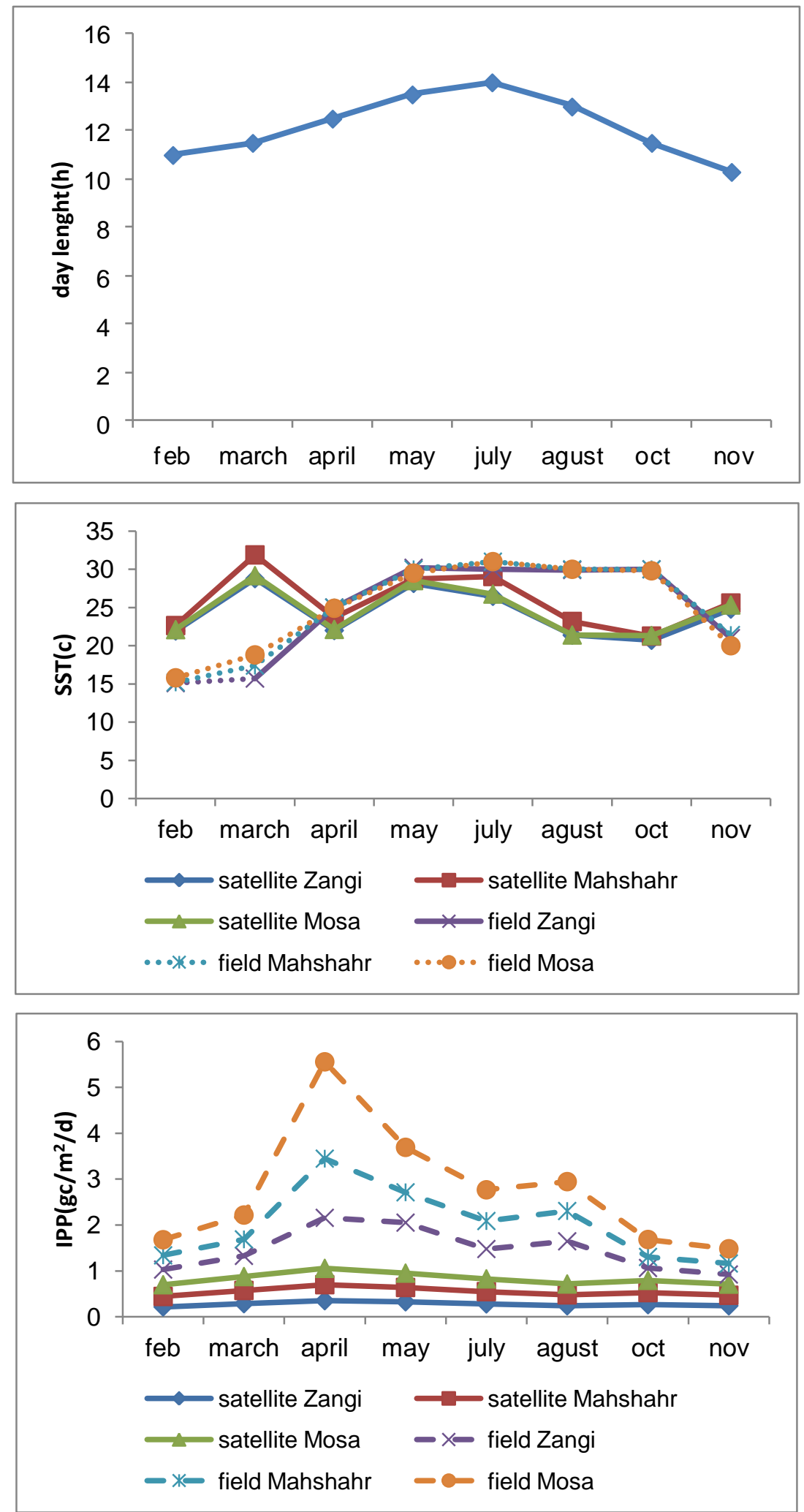

APPLIED ECOLOGY AND ENVIRONMENTAL RESEARCH 14(4): 461-475.

http://www.aloki.hu • ISSN 15891623 (Print) • ISSN 17850037 (Online)

DOI: http://dx.doi.org/10.15666/aeer/1404_461475

(c) 2016, ALÖKI Kft., Budapest, Hungary 


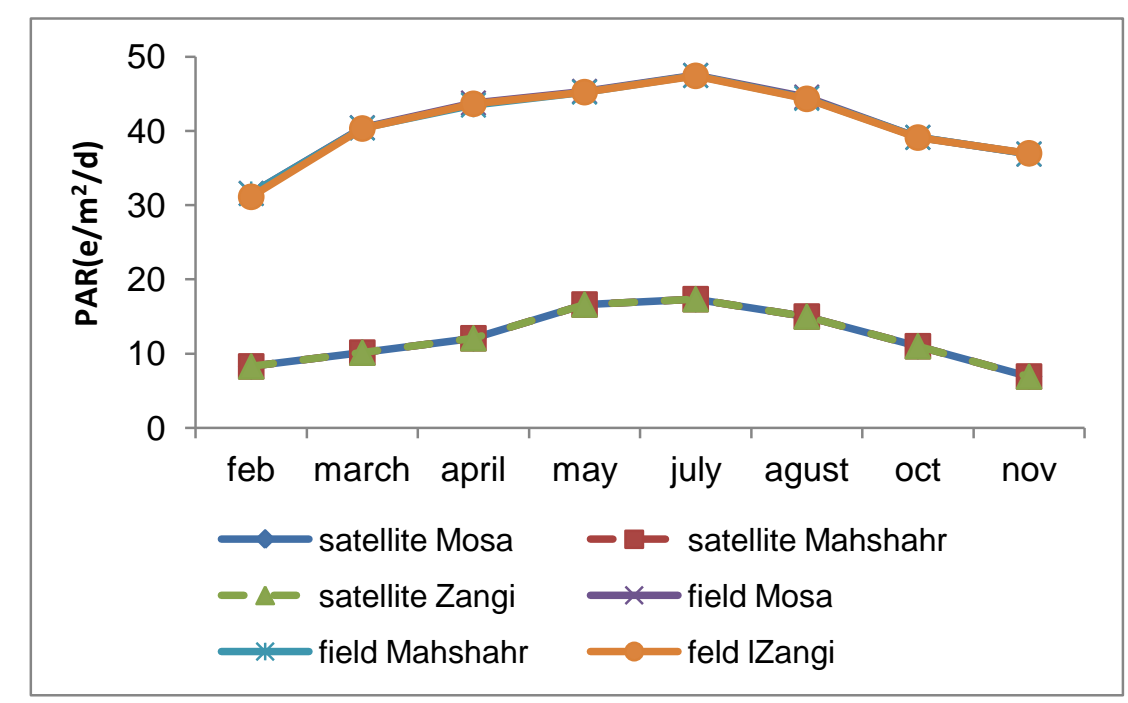

Figure 2. Temporal variations of $E_{0}, S S T$, Chla, DL, $P_{o p t}^{B}, Z_{e u}, K_{d}(490)$ and IPP observed in this study

Among sea surface variables, Chla and $\mathrm{K}_{\mathrm{d}}(490)$ showed a significant linear relationship $\left(\mathrm{R}^{2}=0.35, \mathrm{R}^{2}=0.34\right)$ with measured IPP (Fig. 3). There was no significant relationship between measured IPP and SST (Fig. 3). The highest IPP measured in April that coincided with the highest amount of Chla seemed to be an outlier value from the seasonal variation (Fig. 2). VGPM accounted for $60 \%$ of variation in measured IPP (Fig. 3).

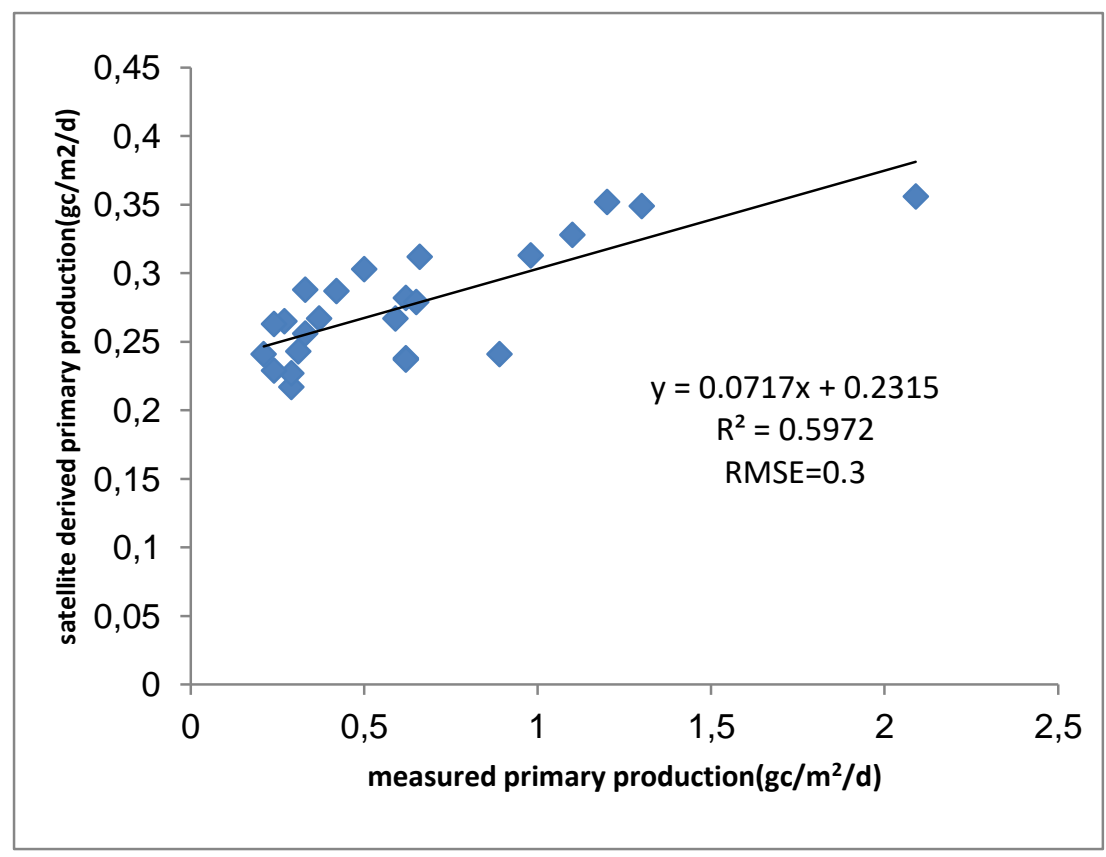



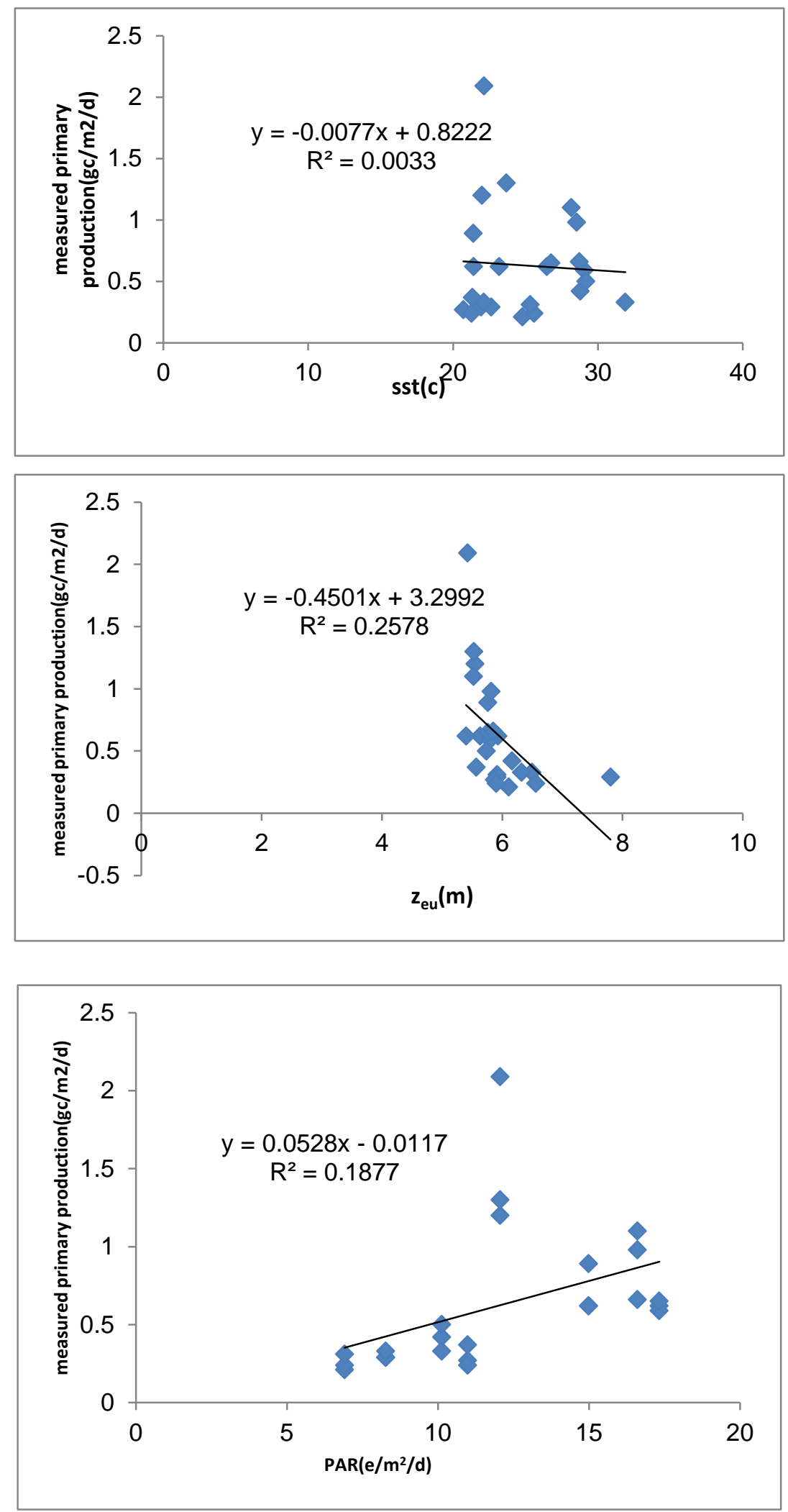

APPLIED ECOLOGY AND ENVIRONMENTAL RESEARCH 14(4): 461-475. http://www.aloki.hu • ISSN 15891623 (Print) • ISSN 17850037 (Online) DOI: http://dx.doi.org/10.15666/aeer/1404_461475 (c) 2016, ALÖKI Kft., Budapest, Hungary 

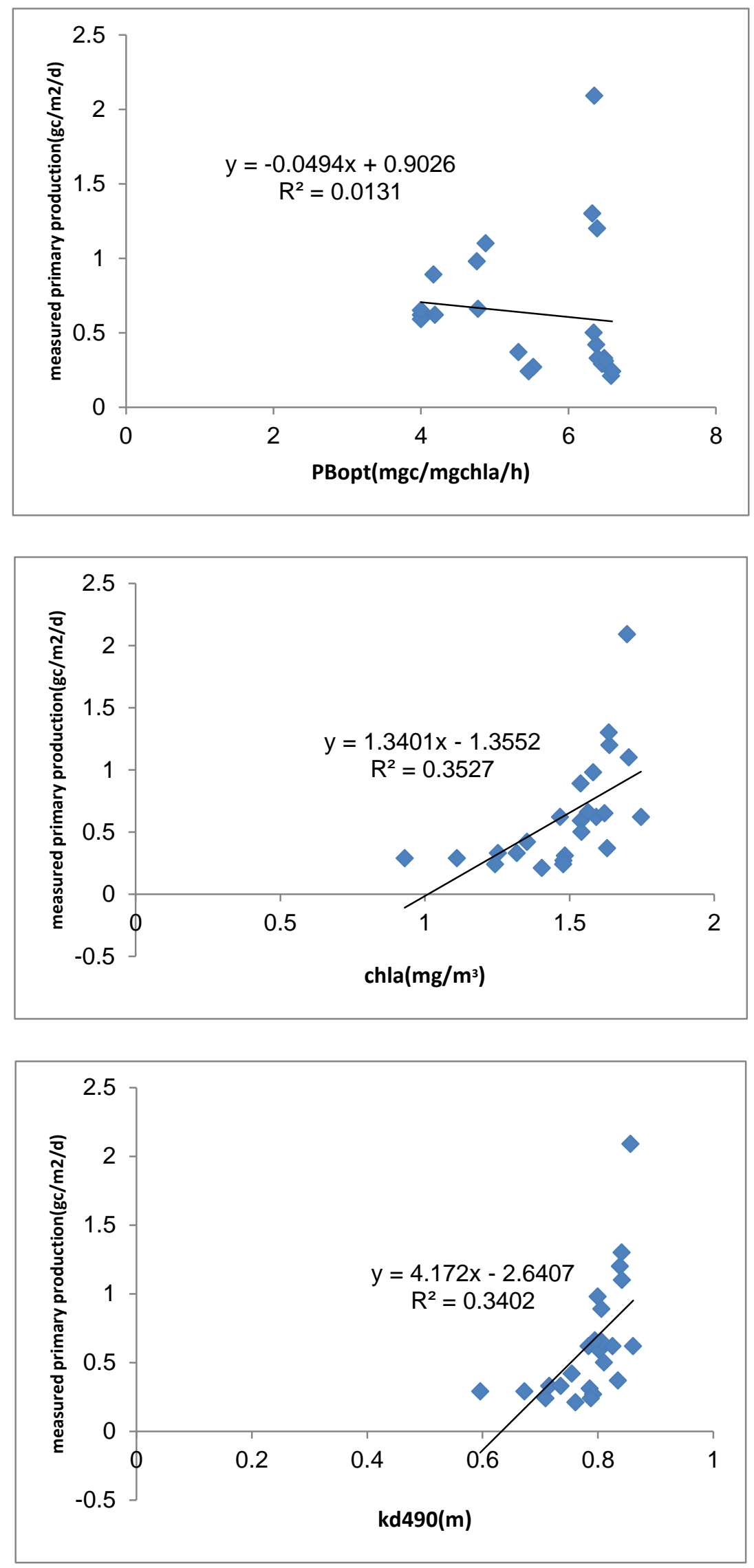

APPLIED ECOLOGY AND ENVIRONMENTAL RESEARCH 14(4): 461-475. http://www.aloki.hu • ISSN 15891623 (Print) • ISSN 17850037 (Online) DOI: http://dx.doi.org/10.15666/aeer/1404_461475 (c) 2016, ALÖKI Kft., Budapest, Hungary 


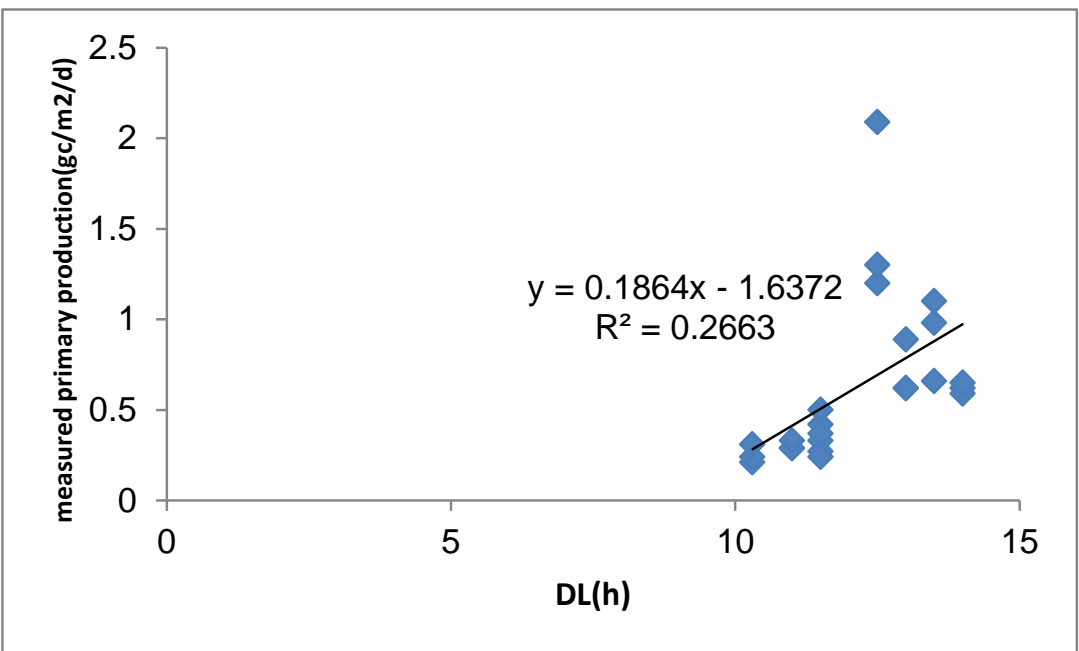

Figure 3. Relationships between measured IPP and $E_{0}, S S T, K_{d}(490), Z_{e u}, D L, S S T, P_{o p t}^{B}$ Chla and satellite primary production

Regression model were used to modification of VGPM model in this region (Table 1 and 2).

Table 1. Results of the regression analysis for models describing production $(P)$

\begin{tabular}{|l|l|l|l|l|l|}
\hline model & df & Sum of squares & Mean square & F & sig \\
\hline regression & 5 & 2.680 & 0.536 & 5.937 & 0.005 \\
residual & 13 & 1.174 & 0.090 & & \\
total & 18 & 3.854 & & & \\
\hline
\end{tabular}

Table 2. Results of the coefficient regression analysis for models

\begin{tabular}{|l|l|l|l|l|l|}
\hline model & $\mathrm{B}$ & Std.Error & Beta & $\mathrm{t}$ & $\mathrm{Sig}$ \\
\hline Constant & -05.932 & 3.838 & & -1.546 & 0.146 \\
Chla & 0.492 & 0.827 & 0.214 & 0.596 & 0.562 \\
$\mathrm{Z}_{\text {eu }}$ & -1.126 & 0.322 & -0.146 & -0.393 & 0.701 \\
$\mathrm{P}^{\mathrm{B}}{ }_{\text {opt }}$ & 0.453 & 0.115 & 1.005 & 3.934 & 0.002 \\
$\mathrm{E}_{0} / \mathrm{E}_{0}+4.1$ & 1.601 & 2.348 & -0.134 & -0.682 & 0.507 \\
$\mathrm{DL}$ & $0 / 456$ & 0.109 & 1.226 & 4.170 & 0.001 \\
\hline
\end{tabular}

The fitted result after regressive analysis is:

$$
\mathrm{IPP}=-5.932+0.492 \cdot \mathrm{Chla}-1.126 \cdot \mathrm{Z}_{\mathrm{eu}}+0.453 \cdot \mathrm{P}^{\mathrm{B}}{ }_{\mathrm{opt}}+1.601 \cdot\left[\mathrm{E}_{0} /\left(\mathrm{E}_{0}+4.1\right)\right]+0.456 \cdot \mathrm{DL} \quad(\mathrm{Eq} .5)
$$

where $Z_{\text {eu }}$ is euphotic depth, $E_{0}$ is surface PAR, and DL is day length.

A third polynomial regression relationship between $P^{B}{ }_{\text {opt }}$ and SST was derived to parameterize $\mathrm{P}^{\mathrm{B}}{ }_{\text {opt }}$ :

$$
\mathrm{P}_{\text {opt }}^{\mathrm{B}}=-2.32 \times 10^{-1}+4.34 \times 10^{-2} \mathrm{SST}+1.00 \times 10^{-3} \mathrm{SST}_{2}-5.00 \times 10^{-5} \mathrm{SST}_{3} \text { (Eq. 6) }
$$


Comparing the data of the measured IP with those of the model calculations using Eq. (1), the correlation coefficient $\left(\mathrm{R}^{2}\right)$ is 0.90 (Fig. 4). Monthly variability of primary productivity from Feb to Nov in Khure-Mussa are shown in Figure 5.

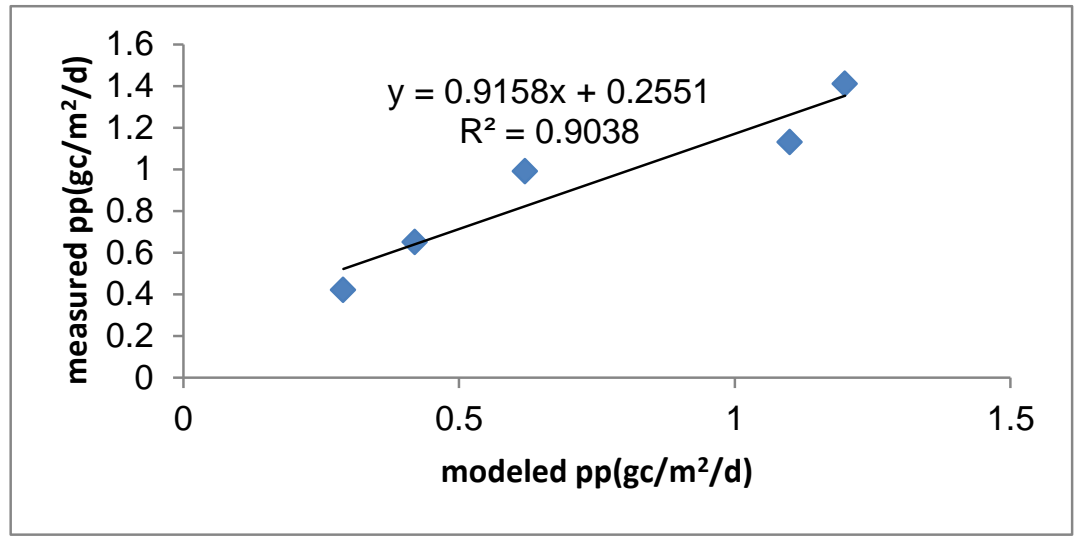

Figure 4. Relationship between the measured IP and model IP as calculated from Eq.I described in the text.

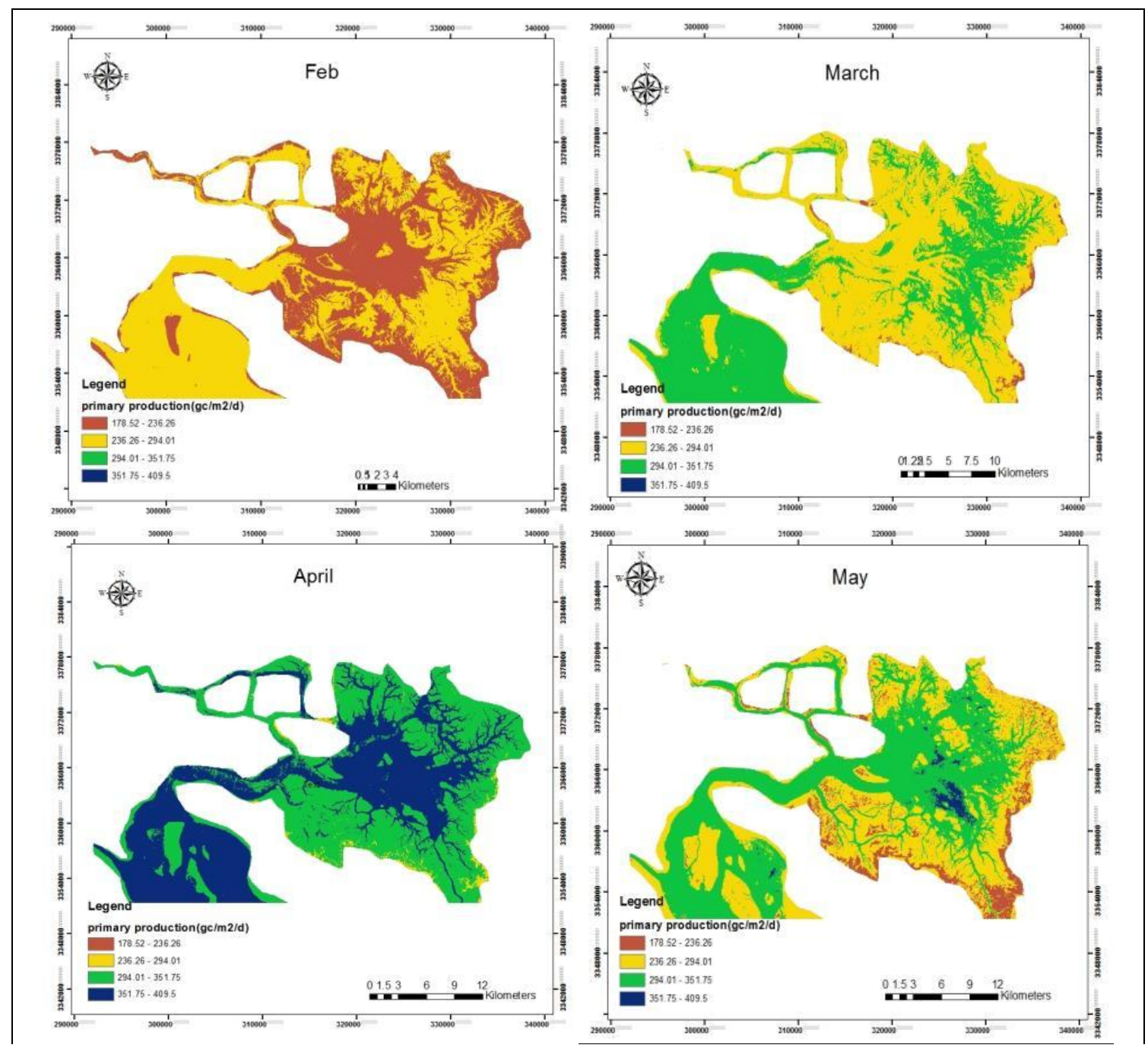




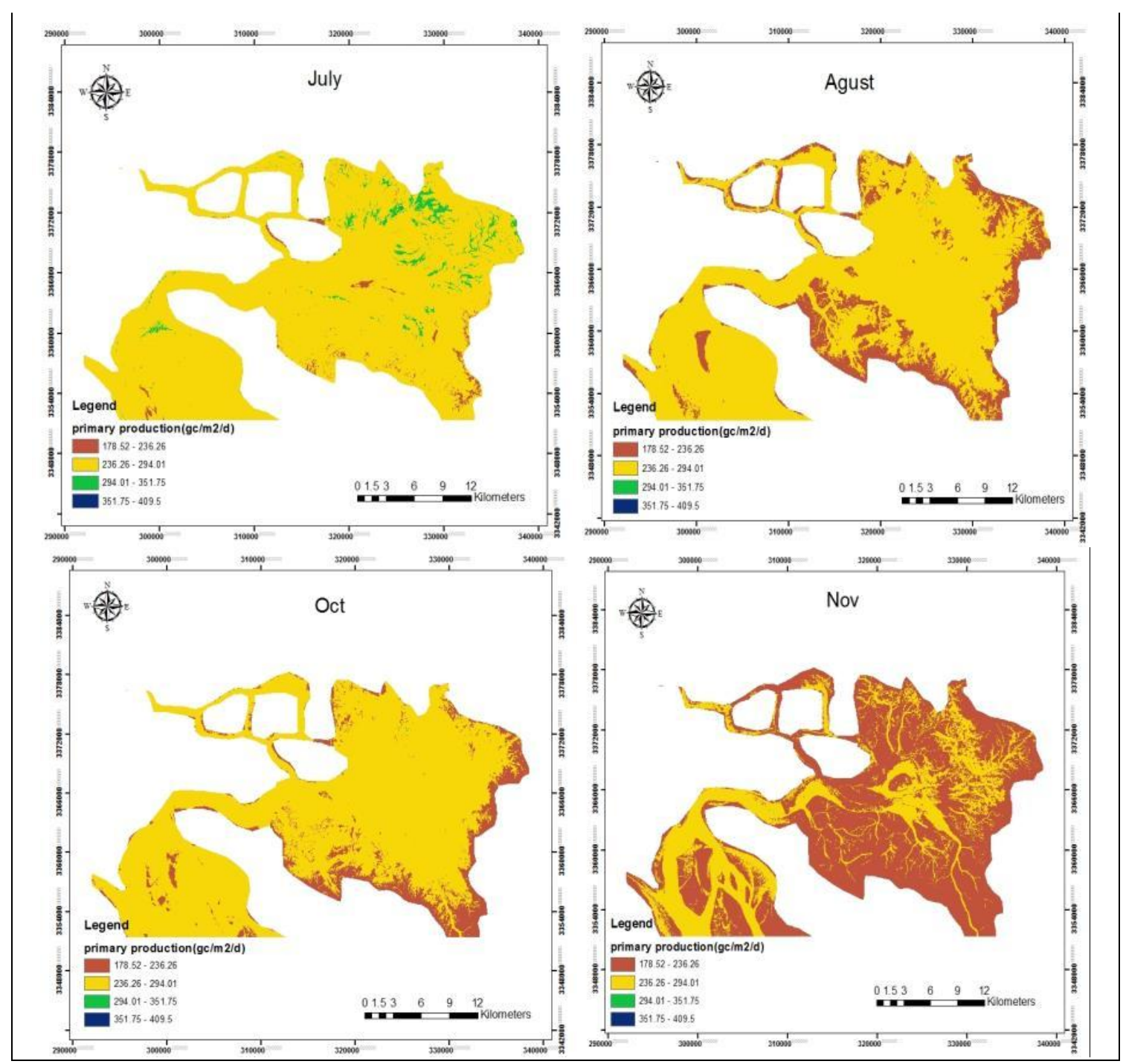

Figure 5. Landsat8 measured monthly NPP images for the Khure-Mussa

\section{Discussion}

After excluding the highest measured IPP, which was presumably an outlier, DL and Chla were more important factors in determining variation in measured IPP than others (Table 1). Many studies have also shown that the greater variance of measured IPP can usually be captured by including Chla and DL, along with variables amenable to remote sensing (e.g. Peierls et al., 2012; Banse and Postel, 2003). In this study, $\mathrm{P}^{\mathrm{B}}{ }_{\text {opt }}$ increased consistently even at $\mathrm{SST}>28^{\circ} \mathrm{C}$, similar to the observations in southeastern Caribbean Sea, with a consistent increase in $\mathrm{P}^{\mathrm{B}}$ opt even at SST as high as $29^{\circ} \mathrm{C}$ (Muller-Karger et al., 2004). Comparisons of model-derived and in situ NPP show the new approach to generate $\mathrm{P}^{\mathrm{B}}$ opt significantly improves retrievals for the Khure-Mussa. Landsat8 NPP are lowest in winter and fall for the entire Khure-Mussa, due to limited light availability. The daily average of primary productivity in the whole Khore-Mussa is $0.63 \mathrm{gcm}^{-2} \mathrm{~d}^{-1}$. Comparison of the historical investigated result of primary productivity in the other subtropical zone has shown in Table 3. 
Table 3. Comparison of the historical investigated result of primary productivity in the other subtropical zone

\begin{tabular}{|l|l|l|}
\hline ecosystems & $\begin{array}{l}\text { Annual mean } \\
\text { primary } \\
\text { production(gc/m²/y) }\end{array}$ & $\begin{array}{l}\text { Refrences } \\
\text { (Purvaja and Ramesh, } \\
\text { 2000) }\end{array}$ \\
\hline Ennore creek & 157 & $\begin{array}{l}\text { (Kang and Kang, } \\
\text { 2005) }\end{array}$ \\
\hline Ilkwang bay & 200 & $\begin{array}{l}\text { (Krishna Kumari et } \\
\text { al., 2002) }\end{array}$ \\
\hline $\begin{array}{l}\text { Mandovi-Zuari } \\
\text { estuarine } \\
\text { complex }\end{array}$ & 300 & (Ara et al., 2011) \\
\hline Mikawa bay & 770 & (Ara et al., 2011) \\
\hline Osaka bay & 825 & (Ara et al., 2011) \\
\hline Sagami bay & 366 & (Ara et al., 2011) \\
\hline Shijiki bay & 292 & This study \\
\hline Khure-Mussa & 230 & \\
\hline
\end{tabular}

Distributions shown in Fig. 5 indicate that Khure-Mussa is characterized by a longitudinal gradient in primary productivity, that productivity increases seaward. Hence our perception of estuaries as highly productive ecosystems should be qualified with the observation that phytoplankton productivity can be higher in nearby coastal waters where the photic zone is deeper and nutrient concentrations are still sufficient to sustain algal growth. Because light availability controls productivity it must also play a major role in determining the population growth rate of estuarine phytoplankton, and we expect that biomass should vary across spatial gradients in the ratio of photic depth to mixed depth.

NPP is highest in spring (April) in Khure-Mussa. The increasing trend in Net Primary Production may be related to the increases in nutrient, reduced grazing losses to benthic suspension feeders (Dehghan Madiseh et al., 2012), phytoplankton biomass and light availability. Seasonal variations in SPM concentration can also influence light penetration and phytoplankton dynamics. In Khure-Mussa, bottom resuspension intensifies during mid-summer when wind speed and mean tidal current speed are both rapid. As a consequence, SPM concentration increases, Zeu decreases, growth rates are near zero, and phytoplankton biomass is low in during mid-summer. Physical processes operating within estuaries (horizontal and vertical mixing, advection, sediment suspension, light absorption) and across their interfaces with watersheds (freshwater, nutrient, sediment input), the coastal ocean (tidal oscillations, exchanges of salt, heat, nutrients, plankton and predators), and atmosphere (heat exchange, wind stress, photon flux to the water surface) all play essential roles in driving the variability of phytoplankton production in ecosystems at the land-sea interface (Cloern et al., 2014).

\section{Conclusions}

Match-up analyses show that Landsat8 NPP compares favorably with in situ NPP, despite limitations of sample size due to a short temporal overlap. Interannual 
variability in NPP in the Khure-Mussa would be positively (lower Bay) or negatively (upper Bay) related to freshwater flow from the rivers, particularly the Arvand and Shatolarab River, sediment suspension, tidal oscillations, wind stress and light availability. The regional daily NPP model for the Khure-Mussa has been improved for use with satellite ocean color data and landsat-derived NPP data corresponding reasonably well with in situ measurements.

\section{REFERENCES}

[1] Ara, K. ,Yamaki, K. ,Wada, K., Fukuyama, S., Okutsu, T., Nagasaka, S., Shiomot, A., Hiromi, J.( 2011): Temporal variability in physicochemical properties, phytoplankton standing crop and primary production for 7 years (2002-2008) in the neritic area of Sagami Bay.- Japan.- Journal of Oceanography 67: 87-111.

[2] Banse, K., Postel, R.(2003): On using pigment-normalized, light-saturated carbon uptake with satellite-derived pigment for estimating column photosynthesis. -Global Biogeochem. - Cycles 17: 10-21.

[3] Behrenfeld, M.J., Falkowski, P.(1997): Consumers guide to phytoplanktonprimary productivity models. - Limnology and Oceanography 42:1479-1491.

[4] Behrenfeld, M .J., Marañó, E,. Siegel, D.A., Hooker, S.B. ( 2002): A photoacclimation and nutrient based model of light-saturated photosynthesis for quantifying oceanic primary production. - Marine Ecology Progress Series 228: 103- 117.

[5] Campbell, J., Antoine, D., Armstrong, R., Balch, W., Barber, R., Beherenfeld, M., Bidigare, R., Bishop, J., Carr, M.E., Esaias, W., Falkowski, P., Hoepffner, N., Iverson, R., Kiefer, D., Lohrenz, S., Marr, J., Morel, A., Ryan, J., Vedernikov, V., Waters, K., Yentsch, C., Yoder, J.(2002): Comparison of algorithms for estimating ocean primary production from surface chlorophyll, temperature, and irradiance. - Global Biogeochemical Cycles 16:34-45.

[6] Carr, M. E, Friedrichs, M., Schmeltz, M. N., Aita, D., Antoine, K. R., Arrigo, I., Asanuma, O., Aumont, R., Barber, M., Behrefeld, R., Bidigare, E.T., Buitenhuis, J., Campbell, A., Ciotti, H., Dierssen, M., Dowell, J., Dunne, W., Esaias, B., Gentili, W., Gregg, S., Groom, N., Hoepffner, J., Ishizaka, T., Kameda, C.(2006): A compariosn of global estimates of marine primary pro-duction from ocean color. - Deep-Sea Res. II 53: 741-770.

[7] Cloern, J.E., Foster, S. Q., Kleckner, A. E.(2014): Phytoplankton primary production in the world's estuarine-coastal ecosystems. - Biogeosciences 11:2477-2501.

[8] Dehghan Madiseh, S., Esmaily, F., Marammazi, J., Koochaknejad, E., Farokhimoghadam, S.(2012): Benthic invertebrate community in Khur-e-Mussa creeks in northwest of Persian Gulf and the application of the AMBI (AZTI's Marine Biotic Index). - Iranian Journal of Fisheries Sciences 11:460-474.

[9] Gong, G., Liu, G.(2003):An empirical primary production model for the East China Sea. Continental Shelf Research 23: 213-224.

[10] Habibi Khaledi, T.(2001): Investigation of the effect if physiochemical factors on primary production and Chl-a in Moussa creek. - Journal of fishery science 4:22-45.

[11] Hooker, S.B., Clauster, H., Ras, J., Van Heukelem, L., Berthon, J.F, Targa, C., Van Der Lined, D., Barlow, R.(2000): The First SeaWiFS HPLC Analysis Round-Robin Experiment. In: NASA Technical Memorandum (NASA Goddard Space Flight Center, Greenbelt, MD), pp.1- 42.

[12] Hopner, T., Kazem Maraschi, S.M.(1999): Intertidal Treasure Khure Mussa-Unrevised. Wadden Sea Newsletter, pp. 3-6.

[13] Kameda, T. ( 2003): Phytoplankton distribution in the East China Sea detected by ocean color remote sensing. - Proc. the $5^{\text {th }}$ Int'l Symp. on Mar. Sci., 1-8. 
[14] Kameda, T., Ishizaka, J.( 2005): Size-fractionated primary production estimated by a twophytoplankton community model applicable to ocean color remote sensing.- Journal of Oceanography 61: 663-672.

[15] Kang, H.K., Kang, Y. J.(2005): Production of Acartia steueri (Copepoda: Calanoida) in Ilkwang Bay, Southeastern Coast of Korea. - Journal of Oceanography 61: 327-334.

[16] Khalfeh Nilsaz, A.( 2000): Investigation of primary production in Mahshahr creeks. MSc. thesis, Khoramshahr University of Science and Technology, Iran. 120p.

[17] Kim, S., Kim, H., Sin, J., Park, S., Park, K. (2014): High resolution ocean color products estimation in fjord of Svalbard, Arctic sea. EARSeL 34th Symposium Proceedings, 16-20 June.

[18] Krishna Kumari, L., Bhattathiri, P.M.A., Matondkar, S.G.P., John, J.( 2002): Primary productivity in Mandovi-Zuari estuaries in Goa. - Journal of marine biology Assesment in India 44:1-13.

[19] Morel, A., Berthon, J. F. (1989):Surface pigments, algal biomass profiles and potential production of the euphotic layer: Relationships reinvestigated in view of remote-sensing applications". - Limnolical Oceanography 34:1545-1562.

[20] Muller-Karger, F., Varela, R., Thunell, Y., Astor, H., Zhang, R., Luerssen, C. (2004): Processes of coastal upwelling and carbon flux in the Cariaco Basin. - Deep-Sea Res., II, 51: 927-943.

[21] Nardello, I., Lazzara, L., Ermanni, C., Mangoni, O., Saggiomo, V. (2013): Light environment and seasonal dynamics of microalgae in the annual sea ice at Terra Nova Bay, Ross Sea, Antarctica. - Antarctic Science 19: 83-92.

[22] Parsons, T.R., Maita, Y., Lalli, C.M. (1984): A Manual of Chemical and Biological Methods for Seawater Analysis. - Pergamon Press, NewYork.

[23] Peierls, B.L., Hall, N.S., Paerl, H.W.(2012): Non-monotonic Responses of Phytoplankton Biomass Accumulation to Hydrologic Variability: A Comparison of Two Coastal Plain North Carolina Estuaries. - Estuary and Coastal 35:1-17.

[24] Platt, T., Caverhill, C. and Sathyandranath, S. (1991): Basin-scale estimates of oceanic primary production by remote sensing: the north Atlantic. - Journal of Geophysics Researchs 96: 147-158.

[25] Platt, T., Sathyendranath, S. (1999): Software for Use in Calculation of Primary Production in the Oceanic Water Column.

[26] Purvaja, R., Ramesh, R.( 2000): Natural and anthropogenic Effects on phytoplankton primary productivity in mangroves. - Chemistry and Ecology 17: 41-58.

[27] Siegel, D., Westberry, M., Brien, N., Nelson, A., Michaels, J., Morrison, A., Scott, E., Caporelli, J., Sorensen, S., Maritorena, S., Garver, E., Brody, B., Ubante, V., Hammer, B. (2001): Bio-optical modeling of primary production on regional scales:the Bermuda BioOptics project. - Deep-Sea Research II 48:1865-1896.

[28] Son, S., Wang, M., Harding Jr., L. W.(2014): Satellite-measured net primary production in the Chesapeake Bay, Remote Sens. - Environmental research 144:109-119.

[29] Tripathy, S.C,. Ishizaka, J., Siswanto, E., Shibata, T. (2012): Modification of the vertically generalized production model for the turbid waters of Ariake Bay, southwestern Japan, Estuarine. - Coastal and Shelf Science 97:66-77.

[30] Walsh, J.J., Dieterle, D.A., Maslowski, W., Whitledge, T.E. (2004): Decadal shifts in biophysical forcing of marine food webs in the Arctic: numerical consequences. -Journal of Geophysical Research 109:123-145.

[31] Wright, S.W., Jefery, S.W., Mantura, R.F.C., Lewellyn, C.A., Bjoerland, T., Repeta, D., Welschemeyer, N. (1991): Improved HPLC method for the analysis of chlorophylls and carotenoids from marine phytoplankton.- Limnolgical Oceanography 12: 77-183. 